\title{
REVIEW
}

\section{A Review on Green Trend for Oil Extraction Using Subcritical Water Technology and Biodiesel Production}

\author{
Weal Abdelmoez* , Eman Ashour and Shahenaz M. Naguib \\ Chemical Engineering Department, Faculty of Engineering, Minia University, Minia, Egypt
}

\begin{abstract}
It became a global agenda to develop clean alternative fuels which were domestically available, environmentally acceptable and technically feasible. Thus, biodiesel was destined to make a substantial contribution to the future energy demands of the domestic and industrial economies. Utilization of the non edible vegetable oils as raw materials for biodiesel production had been handled frequently for the past few years. The oil content of these seeds could be extracted by different oil extraction methods, such as mechanical extraction, solvent extraction and by subcritical water extraction technology SWT. Among them, SWT represents a new promising green extraction method. Therefore this review covered the current used non edible oil seeds for biodiesel production as well as giving a sharp focus on the efficiency of using the SWT as a promising extraction method. In addition the advantages and the disadvantages of the different biodiesel production techniques would be covered.
\end{abstract}

Key words: biodiesel, non-edible oils, subcritical water, esterification, transestrification

\section{Introduction}

Energy consumption was inevitable for human existence. There were various reasons for the search of an alternative fuel that was technically feasible, environmentally acceptable, economically competitive, and readily available. The first foremost reason was the increasing demand for fossil fuels in all sectors of human life, be it transportation, power generation, industrial processes, and residential consumption. The second reason was that fossil - fuel resources were non-renewable, and they will be exhausted in the near future. The last reason was the price instability of fuels such as crude oil, which was a serious threat for countries with limited resources. Several alternatives such as wind, solar, hydro, nuclear, biofuel, and biodiesel had been suggested but all of them were still in the research and development stage ${ }^{1)}$. Biodiesel was considered as an important renewable energy source because of its potential to fulfill the energy demand, reduce green house gasses and global warming ${ }^{2}$.

It was well known that in modern economics, energy had the main role in the advancement of all sectors including agricultural, transportation, telecommunication and industrial sectors. As a result, worldwide energy consumption was expected to grow in a faster rate than the population growth. According to the International Energy Agency (IEA), an anticipated increase of 53\% of global energy consumption was foreseen by 2030. Energy had become a key to boost the economic development across the world. Although the fossil fuels were limited and non - renewable, nevertheless the demand of these resources were increasing rapidly ${ }^{3,4)}$.

Therefore, it became a global agenda to develop clean alternative fuels which were domestically available, environmentally acceptable and technically feasible. According to the Energy Policy Act of 1992 (EPACT, US), natural gas, biodiesel, ethanol, electricity and methanol were the main prospective alternative fuels that could reduce global warming, fossil fuels consumption and exhaust emissions. As an alternative fuel, biodiesel was one of the best choices among others due to its environment friendly behavior and similar functional properties with diesel fuel. Using biodiesel in internal combustion engines could play a great role in reducing fossil fuel demand, environmental impact and the adverse effect on human health. Biodiesel derived from vegetable oil ${ }^{5)}$ had been shown to be a potential alternative replacing petroleum -derived diesel oil for diesel engine $^{6}$.

In the production of biodiesel more than $95 \%$ of feed

\footnotetext{
*Correspondence to: Wael Abdelmoez, Chemical Engineering Department, Faculty of Engineering, Minia University, Minia, Egypt E-mail: drengwael2003@yahoo.com Accepted December 29, 2014 (received for review November 26, 2014) Journal of Oleo Science ISSN 1345-8957 print / ISSN 1347-3352 online http://www.jstage.jst.go.jp/browse/jos/ http://mc.manusriptcentral.com/jjocs
} 
stocks came from edible oils. Use of such edible oil to produce biodiesel was not feasible in view of a big gap in demand and supply of such oils as food. Moreover it might cause some problems such as the competition with the edible oil market, which increased both the cost of edible oils and biodiesel. Moreover it would cause deforestation in some countries because more and more forests had been felled for plantation purposes. In order to overcome these disadvantages, many researchers, scientists, technologists as well as Industrialists were interested in non-edible oil sources like palm oil, castor oil, jatropha, jojoba, karanja, neem oil, soap nut, and algae ${ }^{7)}$ which were not suitable for human consumption because of the presence of some toxic components in the oils. Furthermore, non-edible oil crops could be grown in waste lands that were not suitable for food crops and the cost of cultivation was much lower because these crops could still sustain reasonably high yield without intensive care ${ }^{8)}$. However, most non-edible oils contain high free fatty acids. Thus they might require multiple chemical steps or alternate approaches to produce biodiesel, which would increase the production cost, and may lower the ester yield of biodiesel below the standards.

One of the main aims of this review was providing an information on the different available non-edible oil resources for biodiesel production namely castor oil, jatropha, jojoba, karanja, neem oil, soap nut, and algae (Fig. 1 $)^{9,10)}$.

\section{Non-edible oils for biodiesel production}

The availability of any feedstock for biodiesel production depends on the regional climate, geographical locations, local soil conditions and agricultural practices of any country $^{11,12)}$. One of the main reasons that make biodiesel production more convenient as an energy substitute was the accessibility of biodiesel feed stocks worldwide.

It was very important that any potential feedstock for biodiesel production should be attainable at the lowest price and In an abundant compared to diesel in the competitive market .

\subsection{Algae oil (cyanobacteria)}

Algae (micro and macro) oils are one of the best sources for synthesis of biodiesel. Micro algae are classified as diatoms (bacillar-iophyceae), green algae (chlorophyceae), golden brown (chryso-phyceae) and blue-green algae (cyano phyceae). Microalgae may be the potential and economical source of biodiesel because of high yielding feedstock. In microalgae the oil content can exceed $80 \%$ by weight of dry biomass and oil levels of $20-50 \%$ are common in any micro algae.

Micro algae have long been recognized as potentially good sources for bio-fuel production because of their high oil content, rapid biomass production (double their biomass production within $24 \mathrm{~h}$ ) and it is much faster and easier to

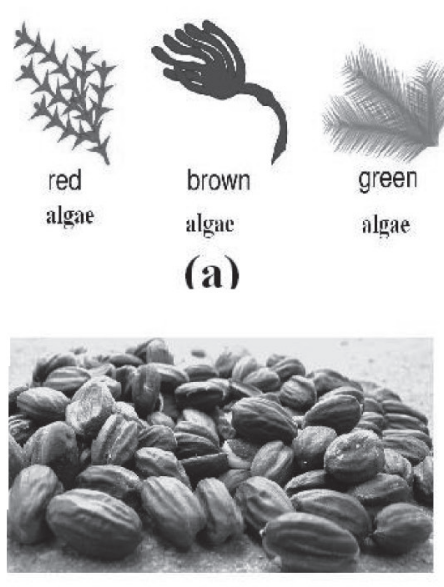

(d)

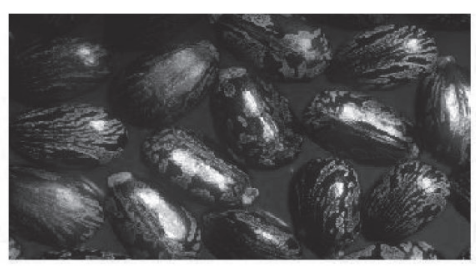

(b)

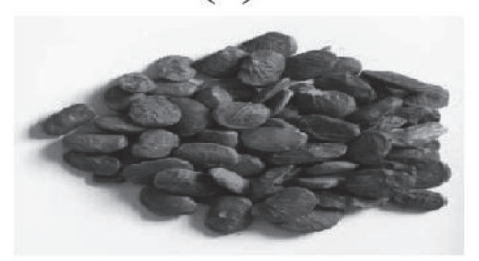

(e)

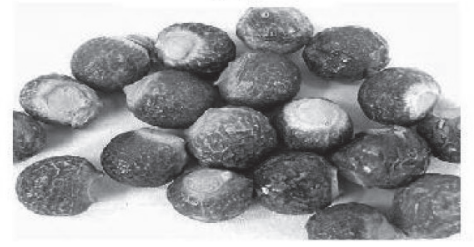

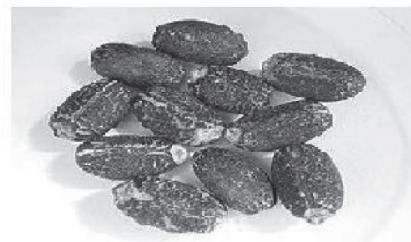

(c)

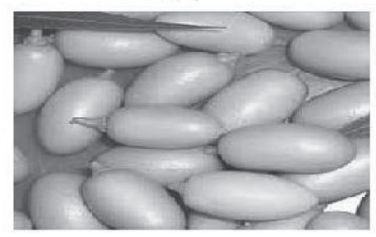

(f)

(g)

Fig. 1 Non - edible oil resources for biodiesel production: (a) algae. (b) castor seed. (c) jatropha seed. (d) jojoba seed. (e) karanja seed. (f) neem seed. (g) soap nut seed. 
grow $^{13,14)}$.

\subsection{Castor oil (Ricinus communis)}

Castor plant has the botanical name $R$. communis of the family Eurphorbiacae ${ }^{15,16)}$. It contains about $46-55 \%$ oil by weight. Castor is originally a tree or shrub that can grow above $10 \mathrm{~m}$ high, reaching an age 4 years. Castor grows in the humid tropics to the sub-tropical dry zones (optimal precipitation $750-1000 \mathrm{~mm}$, temperature $15-38^{\circ} \mathrm{C}$ ). The oil of castor plant is viscous, pale yellow, non-volatile, nondrying oil with a bland taste and sometimes used as a purgative and the oil has a slight odor. Relative to other vegetable oils castor oil has a good shelf life and it does not turn rancid unless subjected to excessive heat and is a good source of raw material for varieties of other field like adhesives, coatings, soaps, lubricants, paints and dyes ${ }^{17,18)}$.

\subsection{Jatropha oil (Jatropha curcas L.)}

Jatropha plant has the botanical name $J$. curcas, and it is a multipurpose bush small tree belonging to the family of Euphorbiaceae; it can grow under a wide variety of climatic conditions like severe heat, low rain fall, high rain fall, and is a small deciduous tree (upto5m). The seeds contain $30-35 \%$ oil by weight. Recently Jatropha is being considered as one of the most promising potential oil source to produce biodiesel all over the world. In normal conditions the plant will fruit once a year, yielding $2-5$ tons of dry seed/ha year, after 5 years, depending on the genetic variety, agro-climatical conditions and the management input $^{19,20)}$. The seeds and oil are not edible due to the presence of toxins as phorbol esters, trypsin inhibitors, lectins and phytates. The oil of $J$. curcas consists of both saturated (14.2\% palmitic acid and $7.0 \%$ stearic acid) and unsaturated fatty acids ( $44.7 \%$ oleic acid and $32.8 \%$ linoleic acid). The seeds of Jatropha contain viscous oil, which can be used in soap, cosmetics industry, preparing candles, as a diesel paraffin substitute or extender ${ }^{21,22)}$.

\subsection{Jojoba oil (Simmondsia chinensis)}

The seed of jojoba plant, which has botanical name $S$. chinensis, appears to be a promising scope for cultivation in arid and semi- arid areas. The Jojoba seed is nut shaped and is around 1-2 cm long, with red- brown to dark-brown color. The seed contains 45 and 55 wt\% of Jojoba oil-wax ${ }^{23,24)}$. The chemical structure of jojoba oil allows its use in many lubricating oil formulation and biodiesel production. Jojoba oil and its derivatives find applications in the fields of cosmetics, pharmaceuticals and lubricants ${ }^{25,26)}$.

\subsection{Karanja seed (Pongamia pinnata)}

Pongamia oil is a non-edible oil extracted from seeds of P. pinnata (L.) Pierre, family Fabaceae commonly known as 'Karach', 'Karanja' in Assam. Karanja is medium sized fast-growing ever green tree, 12-15 m height, branches spread into hemispherical crown of dense green leaves. It has a disagreeable odor and bitter taste. Seeds are 10-20 $\mathrm{mm}$ long and light brown in color. Pongamia can survive in adverse conditions like draught, heat, frost, salinity, etc. ${ }^{27,28)}$. The karanja seed kernel contains 27-39 wt\% oil. The oil has been used mainly for leather tanning, lighting and to a smaller extent in soap making, medicine and lubricants ${ }^{29-31)}$.

\subsection{Neem (Azadirachta indica)}

$\operatorname{Neem}(A$. indica $)$ is a fastest-growing tree that can reach a height of 15-20 m. Neem can be grown on very marginal soils that may be very rocky, shallow, dry or pan forming. The neem seed contains $35-45 \%$ of oil. Neem products have been observed advantageous to be anthelmintic, antifungal, antidiabetic, antibacterial, antiviral, contraceptive and sedative. Neem gum is used as a bulking agent and for the preparation of special purpose food (for diabetics) and neem leaf paste is applied to the skin to treat acne ${ }^{32,33)}$.

A neem tree can produce many thousands of flowers, and in one flowering cycle, a mature tree may produce a large number of seeds. Neem trees start bearing harvestable seeds within 3-5 years, and full production may be reached in 10 years, and this will continue up to 150-200 years of age $\mathrm{e}^{34-36)}$.

\subsection{Soap nut (Sapindus mukorossi)}

Soap nut $(S$. mukorossi) is a fruit of the soap nut tree and the plant grows very well in deep loamy soil sand leached soils, so cultivation of soap nut in such soil a voids potential soil erosion. (30\% oil content). Also it was used in a commercial cleanser and medical applications based on its usages including antidermatophytic ${ }^{37-39)}$.

The oil from soap nut had been considered as promising non-edible oil having significant potential for biodiesel production. This was because it was the third most productive vegetable oil producing crop in the world, after algae and oil palm ${ }^{40,41)}$.

\section{Subcritical water technique as extraction method}

Extraction always involved a chemical mass transfer from one phase to another. The principles of extraction were used to advantage in everyday life, for example in making juices, coffee and others. To reduce the use of organic solvent and improve the extraction methods of constituents of plant materials, new methods such as microwave assisted extraction (MAE), supercritical fluid extraction (SFE), accelerated solvent extraction (ASE) or pressurized liquid extraction (PLE) and subcritical water extraction (SWE), also called superheated water extraction or pressurized hot water extraction(PHWE), had been introduced $^{42,43)}$.

Lately, subcritical water technology had attracted many 


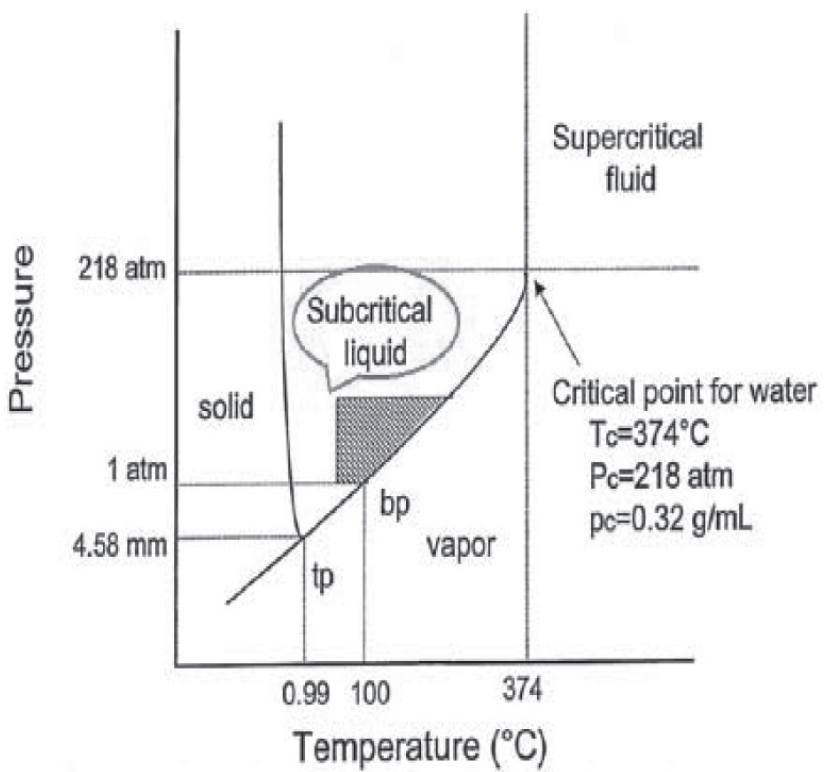

Fig. 2 Phase diagram of water as a function of temperature and pressure (Cross-hatched area indicates the preferred region (SWE)).

researchers for its versatile applications in the field of environment as a green alternative process to solvent extrac$\operatorname{tion}^{44)}$.

The past decade had witnessed an intense interest in the use of subcritical water technology (SWT) in separation processes. SWT was an alternative extraction method where by water instead of organic solvents were used as the extraction media. On heating within the critical point of water (Fig. 2) (temperature $<374{ }^{\circ} \mathrm{C}$, pressure $22.1<$ $\mathrm{MPa})$ under enough pressure to maintain the liquid state, water (subcritical water in this state) was reported to have distinctive properties. These were a low dielectric constant and a high ion product. Many extractable components from different biomass could be easily extracted under these conditions ${ }^{45}$.

Based on the research worked published in the recent years, it had been shown that the SWE was cleaner, faster and cheaper than the conventional extraction methods.

\subsection{Extraction mechanism}

The SWE process could be proposed to have six sequential steps: (1) rapid fluid entry; (2) desorption of solutes from matrix active sites; (3) diffusion of solutes through organic materials; (4) diffusion of solutes through static fluid in porous materials; (5) diffusion of solutes through layer of stagnant fluid outside particles; and (6) elution of solutes by the flowing bulk of fluid. The plots the amount of compound extracted versus solvent flow rates and versus solvent volume can determine the relative importance of these steps. For example, if the rate of extraction was controlled by intra-particle diffusion or kinetic desorp- tion, the increase in bulk fluid flow rate would have little effect on extraction rate. On the other hand, if the extraction was controlled by external film transfer diffusion, extraction rates increase with solvent flow rate ${ }^{46)}$.

\subsection{Example of Oil Extraction Using Subcritical Water Technology (SEW)}

No commercial SWE equipment was available, but the apparatus was easy to construct in the laboratory. SWE was performed in batch or continue systems. The SWE was carried out in a laboratory-built apparatus. After the preparation step, the SCE was carried out in stainless steel pipes with Swadgelok caps. The seeds were then charged into the reactor tube. The reactor was then sealed and immersed in a heating bath containing one of the heating media. The extraction was carried out in the range of 180 $260^{\circ} \mathrm{C}$, and the pressure inside the reactor was estimated from the steam table. After the desired extraction time, the reactor was immediately cooled down by immersing it into a cold-water bath. The extract product contained three phases, the oil phase, the aqueous phase (including oil and water), and the solid phase. The three phases were separated through simple centrifugation and vacuum filtration processes. To recover any traces of oil from the aqueous phase, we added petroleum ether to extract any oil that could be emulsified into the water phase. Then, the petroleum ether was evaporated by heating it in a furnace at $80^{\circ} \mathrm{C}$. The extracted oil was then weighed and the data was recorded $^{47,48)}$.

\subsection{Kinetics study for Oil extraction Using Subcritical Wa- ter Technology}

The oil extraction process could be viewed as an irreversible consecutive unimolecular-type first order. In which, the oil was firstly extracted from inside the seed by diffusion following a first order-like mechanism. Then the extracted oil, due to extending the extraction time under the high temperature and pressure, was subjected to a decomposition reaction following a first order mechanism. Accordingly, the oil extraction process could be simplified into the following reaction scheme,

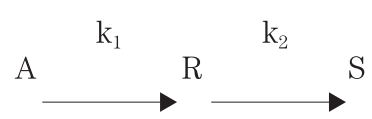

Where, A, R and S, represent the total oil in the seed, extracted oil, and the decomposition product, respectively and $k_{1}$ and $k_{2}$ represent the specific reaction rate constants for the extraction and decomposition steps, respectively.

The rate equations for the three components were:

$$
\begin{aligned}
& \mathrm{dC}_{\mathrm{a}} / \mathrm{dt}=-\mathrm{k}_{1} \mathrm{C}_{\mathrm{a}} \\
& \mathrm{dC}_{\mathrm{r}} / \mathrm{dt}=\mathrm{k}_{1} \mathrm{Ca}-\mathrm{k}_{2} \mathrm{C}_{\mathrm{r}}
\end{aligned}
$$




$$
\mathrm{dC}_{\mathrm{s}} / \mathrm{dt}=\mathrm{k}_{2} \mathrm{C}_{\mathrm{r}}
$$

Where $\mathrm{C}_{\mathrm{a}}, \mathrm{C}_{\mathrm{r}}$ and $\mathrm{C}_{\mathrm{s}}$, represent the concentration of the total oil in the seed, the concentration of extracted oil, and the concentration of decomposition product, respectively.

Integration of the rate equations results in:

$$
-\ln \left(\mathrm{C}_{\mathrm{a}} / \mathrm{C}_{\mathrm{a} 0}\right)=\mathrm{kt} \text { or } \mathrm{C}_{\mathrm{a}}=\mathrm{C}_{\mathrm{a} 0} \mathrm{e}_{1}^{-\mathrm{k} \mathrm{t}}
$$

Where $\mathrm{C}_{\mathrm{a} 0}$ represents the initial concentration of the oil in the seeds. To find the variation in concentration of R, substitute the concentration of A from Eq. 1 into the differential equation governing the rate of change of concentration of the extracted oil; R:

$$
\mathrm{dC}_{\mathrm{r}} / \mathrm{dt}+\mathrm{k}_{2} \mathrm{Cr}=\mathrm{k}_{1} \mathrm{C}_{\mathrm{ao}} \mathrm{e}_{1}^{-\mathrm{k} \mathrm{t}}
$$

by integrating Eq. 5, the final variation in concentration of the extracted oil, $\mathrm{R}$,was:

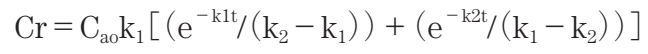

Eq. 6 had been used to elucidate the concentration time course of jojoba oil extraction $^{49)}$.

The kinetic study of the oil extraction from spent bleaching earth (SBE) \& jojoba seed under subcritical water conditions were based on consecutive steps. In these steps, the oil was firstly extracted from inside the powder by diffusion following a first order-like mechanism. Then the extracted oil, due to extending the extraction time under high temperature and pressure, was subjected to a decomposition reaction following a first order mechanism.

The experimental data correlated well with the irreversible consecutive unimolecular-type first order mechanism using Eq. 6. The values of both oil extraction rate constant and decomposition rate constant were calculated through non-liner fitting using DataFit software. Table 1 kinetic \& thermodynamic study of oil extraction from spent bleaching earth (SBE) \& jojoba seed. The extraction rate constants were $0.018,0.03,0.08,0.1$ and $0.14 \mathrm{~min}^{-1}$, while the decomposition rate constants were $0.016,0.012,0.02$,
0.025 and $0.0205 \mathrm{~min}^{-1}$ at extraction temperatures of 180 , $230,250,260$ and $270^{\circ} \mathrm{C}$, respectively for SBE \& The values of both oil extraction rate constants and the decomposition rate constants for jojoba were 0.0094, 0.0187, and 0.1154 $\min ^{-1}$, while the decomposition rate constants were $0.0985,0.1074$, and $0.0078 \mathrm{~min}^{-1}$ at extraction temperatures of 180,200 , and $240^{\circ} \mathrm{C}$, respectively. The results showed that by increasing the extraction temperature, the extraction rate increases. However, the decomposition rate increased up to a certain value then became almost constant by increasing the extraction temperatures.

The results showed that by increasing the extraction temperature, the extraction rate increases. However, the decomposition rate decreased by increasing the extraction temperatures. Such phenomena could be explained on the basis of a compensation mechanism. Such mechanism could be viewed as follows: by increasing the extraction temperature, part of the fat phase decomposes into the oil phase, resulting in an increase in the oily content and a decrease in the apparent overall decomposition step. However, by increasing the extraction time, part of the degradable products is finally decomposed into the gas phase (as mentioned above), resulting in the reduction of the overall mass balance. This point needs more investigation and analysis.

\subsection{Thermodynamic study for Oil extraction Using Sub- critical Water Technology}

The oil extraction process was also analyzed thermodynamically. Arrhenius was used for describing the temperature dependence of the reaction rate. The Arrhenius equation is founded on the empirical observation and commonsense, that is, the Chemical Perception which suggests that the higher the temperature the faster is a given chemical reaction will proceed (Eq. 7).

$$
\mathrm{K}=\mathrm{A} \exp \left[-\mathrm{E}_{\mathrm{a}} / \mathrm{RT}\right]
$$

\begin{tabular}{|c|c|c|c|c|}
\hline Temperature $\left({ }^{\circ} \mathrm{C}\right)$ & \multicolumn{2}{|c|}{ Oil Extraction Rate, $\mathrm{k},\left(\mathrm{min}^{-1}\right)$} & \multicolumn{2}{|c|}{ Oil Decomposition Rate, $\mathrm{k},\left(\mathrm{min}^{-1}\right)$} \\
\hline \multirow[t]{2}{*}{180} & $\begin{array}{l}\text { Spent Bleaching } \\
\text { Earth }(\mathrm{SBE})\end{array}$ & jojoba & $\begin{array}{l}\text { Spent Bleaching } \\
\text { Earth }(\mathrm{SBE})\end{array}$ & jojoba \\
\hline & 0.018 & 0.00948 & 0.016 & 0.0985 \\
\hline 260 & 0.1 & 0.0944 & 0.025 & 0.01322 \\
\hline Activation energy, E (KJ/mol) & 46.1 & 82.5 & & \\
\hline Frequency, $\mathrm{A}\left(\mathrm{min}^{-1}\right)$ & 3084.05 & 464483 & & \\
\hline \multicolumn{5}{|c|}{$\begin{array}{l}\text { Standard Gibbs free energy of activation, } \\
\Delta \mathrm{G}^{\#}\left(\mathrm{~kJ} \cdot \mathrm{mol}^{-1}\right) \text { at temperature : }\end{array}$} \\
\hline 180 & 44.3 & Not measured & & \\
\hline 260 & 59.5 & Not measured & & \\
\hline
\end{tabular}

Where $\mathrm{A}$ is the pre-exponential factor (sometimes called

Table 1 Kinetic \& thermodynamic study of oil extraction from spent bleaching earth (SBE) \& jojoba seed. 
frequency factor), $\mathrm{E}$ is the apparent activation energy, $\mathrm{T}$ is the absolute temperature, and $\mathrm{R}$ is the gas constant (8.31451 J. $\left.(\mathrm{mol} . \mathrm{K})^{-1}\right)$.

On the integration of both sides of Eq. 7:

$\operatorname{Ln} \mathrm{k}=-\mathrm{E}_{\mathrm{a}} / \mathrm{RT}+\ln \mathrm{A}$

By plotting ln k vs. 1/T, a linear relationship is obtained and one can determine Ea from the slope $(-\mathrm{Ea} / \mathrm{R})$ and $\mathrm{A}$ from the $\mathrm{y}$-intercept. This equation assumes that Ea and $\mathrm{A}$ are constants or nearly constant with respect to temperature $^{50)}$

The activation thermodynamic parameters were calculated from the transition-state theory using the Eyring equation. Eyring (1935) formulated his equation, which represents a theoretical construct, based on transitionstate theory. The Eyring equation in its thermodynamic version becomes:

$$
\begin{aligned}
& k=\left(k_{b} T / h\right) e^{-\Delta G \# / R T} \\
& k=\left(k_{b} T / h\right) e^{\Delta S \# / R} e^{-\Delta H \# / R T}
\end{aligned}
$$

where $\mathrm{k}$ is the rate constant, $\Delta \mathrm{G}^{\#}$ is the standard Gibbs free energy of activation, $\Delta \mathrm{H}^{\#}$ is the standard enthalpy of activation, $\Delta S^{\#}$ is the standard entropy of activation, $k_{b}$ is the Boltzmann constant $\left(1.380658 \times 10-23 \mathrm{~J} . \mathrm{K}^{-1}\right)$, h is Planck's constant $(6.6260755 \times 10-34 \mathrm{~J} . \mathrm{s}), \mathrm{R}$ is the gas constant, and $\mathrm{T}$ is the absolute temperature in Kelvin.

On taking a logarithm for both sides of eq. 10, one obtains:

$$
\ln (\mathrm{k} / \mathrm{T})=\left[\ln \left(\mathrm{k}_{\mathrm{b}} / \mathrm{h}\right)+\left(\Delta \mathrm{S}^{\#} / \mathrm{R}\right)\right]-\Delta \mathrm{H}^{\#} / \mathrm{RT}
$$

By plotting $\operatorname{Ln}(\mathrm{k} / \mathrm{T}) \mathrm{vs} .1 / \mathrm{T}$, a linear relationship is obtained and one can determine $\Delta \mathrm{H}$ from the slope which is equal to the value $\left(\Delta H^{\#} / R\right)$ and $\Delta S^{\#}$ is determined from the y-intercept $\left[\ln (\mathrm{kb} / \mathrm{h})+\left(\Delta \mathrm{S}^{\#} / \mathrm{R}\right)\right]$.

The Gibbs free energy of activation can be determined by:

$$
\Delta \mathrm{G}^{\#}=\Delta \mathrm{H}^{\#}-\mathrm{T} \Delta \mathrm{S}^{\#}
$$

In this section, the thermodynamic properties of the oil extraction process were investigated. For spent bleaching earth (SBE), The activation energy, Ea, and the frequency factor, A, were calculated from these values using Eq. 7. Accordingly, the values of Ea and A were $46.1 \mathrm{~kJ} \mathrm{~mol}{ }^{-1}$ and $3084.05 \mathrm{~min}^{-1}$, respectively. To gain a deeper understanding of the extraction process, the activation thermodynamic $\Delta \mathrm{H}^{\#}$ and $\Delta \mathrm{S}^{\#}$ parameters were calculated from the transitstate theory. The standard enthalpy of activation $\left(\Delta \mathrm{H}^{*}\right)$ and the standard entropy of activation $\left(\Delta \mathrm{S}^{\#}\right)$ were calculated using eq. 11. The value of $\Delta \mathrm{H}^{\#}$ was $-42.038 \mathrm{~kJ} . m o l^{-1}$ and the value of $\Delta \mathrm{S}^{\#}$ was $-0.1906 \mathrm{~kJ} . \mathrm{K}^{-1} \cdot \mathrm{mol}^{-1}$. The value of $\Delta \mathrm{S}^{\#}$ gives information about the degree of order in the transition state. Low values of ln A correspond to large negative values of $\Delta S^{\#}$, indicating unfavorable reactions, which means that the activated complex in the transition state has a more ordered or more rigid structure than the reactants in the ground state. The values of the Gibbs free energy $\Delta G^{\#}$ of activation were calculated at different temperatures using eq. 12 were 44.3, 53.8, 57.6, 59.5 and 61.4 kJ.mol ${ }^{-1}$ at $180,230,250,260$ and $270^{\circ} \mathrm{C}$, respectively. The positive values indicate a non-spontaneous reaction while the negative value indicates a spontaneous process. These results explained why high extraction temperatures and pressure were needed for improving the extraction process to overcome the non - spontaneous nature of the process.

\section{Biodiesel production process}

\subsection{Transesterification process}

The most practical and common way of producing biodiesel was by transesterification (also called methanolysis), which was a catalyzed reaction of vegetable oil in the presence of alcohol to yield biodiesel and glycerol ${ }^{28)}$. The process starts with a sequence of three consecutive reversible reactions, wherein triglycerides were converted to diglycerides, diglycerides were converted to monoglycerides, and monoglycerides were converted to glycerol. Each step produces an ester and, as a consequence, generates three ester molecules from one triglyceride molecule. Scheme 1 shows the transesterification chemical equation.

$$
\begin{aligned}
& \mathrm{TG}+\mathrm{MeOH} \Leftarrow \text { Catalyst } \Rightarrow \mathrm{DG}+\mathrm{FAME} \\
& \mathrm{DG}+\mathrm{MeOH} \Leftarrow \text { Catalyst } \Rightarrow \mathrm{MG}+\mathrm{FAME} \\
& \mathrm{MG}+\mathrm{MeOH} \Leftarrow \text { Catalyst } \Rightarrow \mathrm{G}+\mathrm{FAME}
\end{aligned}
$$

where TG, DG and MG refer to tri-, di-, and monoglycerides, respectively, G represents glycerol, and FAME represents fatty acid methyl esters or biodiesel ${ }^{51)}$.

There were various methods for biodiesel production from non edible oils, and The following section gives an overview of various acid, base catalytic (homogeneous, heterogeneous) and non-catalytic processes reported so far for biodiesel production.

4.1.1 Homogeneous transesterification

Homogeneous catalysts can be base catalysts, such as sodium hydroxide $(\mathrm{NaOH})$ and potassium hydroxide $(\mathrm{KOH})$, or acid catalysts, such as sulphuric, sulphonic, phosphoric, and hydro- chloric acids. Base catalysts were preferred over acid catalysts because they have higher catalytic efficiency, lower cost, and lower reaction temperature and pressure. However, base catalysts may react with FFA present in the feedstock during transesterification, resulting in soap formation by saponification, which may consume the catalyst and reduce its efficiency ${ }^{52)}$.

Nevertheless, two- step catalyzed transesterification (Fig. 3) had been proven effective in the production of bio- 


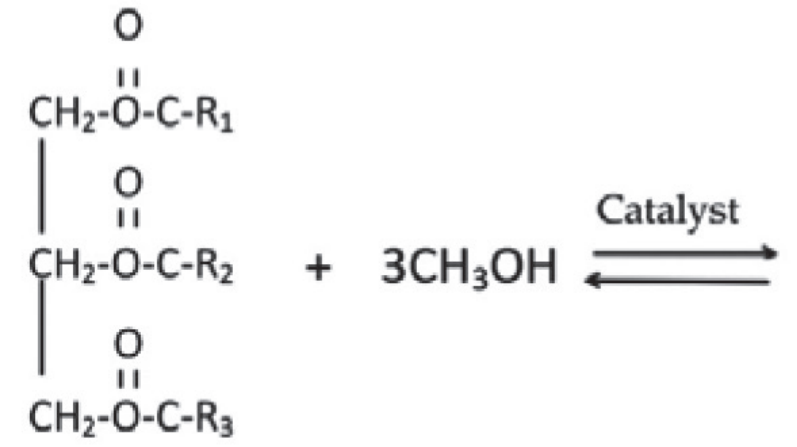

Triglyceride

Methanol

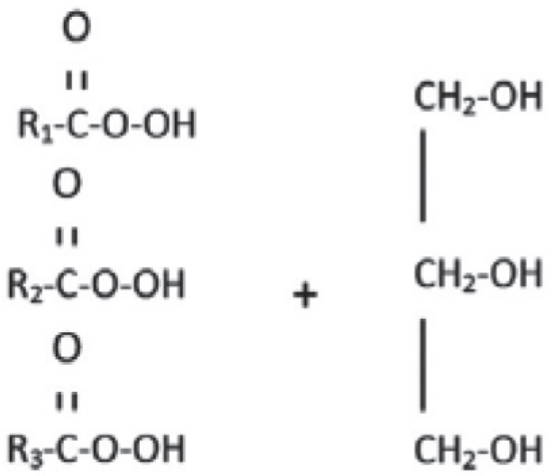

Esters
Glycerol

Scheme 1 shows the transesterification chemical equation.

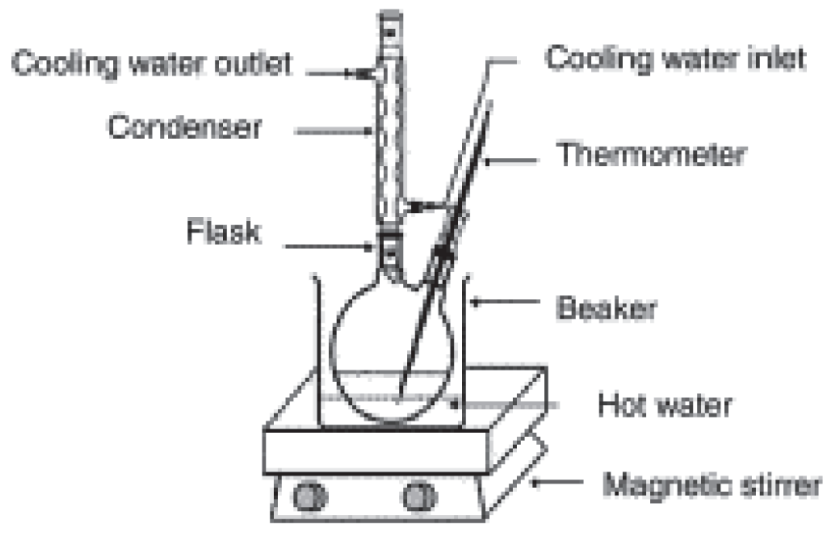

Fig. 3 Two - step catalyzed method ${ }^{31)}$.

diesel from feed- stock that contains a large amount of FFA. In this method, both acidic and basic catalysts were used separately: the acidic catalyst, such as sulphuric acid, was used in the first step, the esterification of FFA, whereas the basic catalyst was used in the second step, in the triglyceride's transesterification. However, in this method, catalysts were removed after each step, according to Bautista et al. In contrast, Guzatto et al. used a modified double - step process, which uses the basic catalyst in the first step and the acidic catalyst in the second, reducing the overall process time and catalyst concentration ${ }^{53)}$.

4.1.2 Heterogeneous transesterification

Just like homogeneous catalysts, heterogeneous catalysts were also of two types, namely, acidic and basic. Examples of heterogeneous acid catalysts were sulphated metal oxide, hetero - polyacids , acidic ion exchange resin, and sulphonated amorphous catalysts. Additional examples of hetero-generous base catalysts include zinc oxide $(\mathrm{ZnO})$, calcium oxide $(\mathrm{CaO})$, strontium oxide $(\mathrm{SrO})$, and $\mathrm{Na} / \mathrm{SiO}_{2}{ }^{54)}$.

However, heterogeneous catalysts may not be practical at an industrial scale because of their high excess alcohol requirements, high reaction temperatures, long reaction

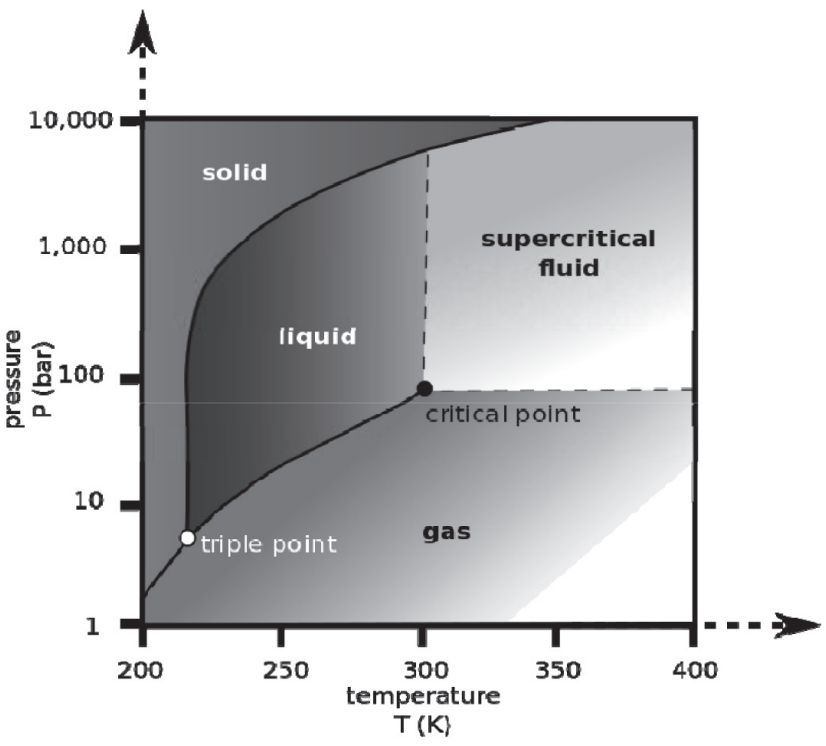

Fig. 4 Supercritical condition.

times, and high energy consumption The type of a heterogeneous catalyst for the biodiesel production from non-edible vegetable oils depends on the FFA content in the feed$\operatorname{stock}^{55)}$.

The solid acid catalysts were insensitive to FFA content, esterification and transesterification occur simultaneously, avoids the washing step of biodiesel, separation of the catalyst from the reaction medium was easy, low product contamination, easy regeneration, recycling of catalyst and reduced corrosion problem even with the presence of acid species $^{56)}$.

4.1.3 Supercritical transesterification

A supercritical methanol transesterification process (Fig. 4) had several advantages over the conventional process in terms of the elimination of catalysts, easier separation of products, faster reaction rate, elimination of FFA and water contents on the ester yield, and elimination of soap formation. However, supercritical transesterification requires 
high reaction temperature and pressure, a large excess of alcohol, high energy consumption, and high capital cost. This supercritical process allowed feedstock containing certain amount of water and FFA. High reaction rate and without using any catalyst were also its advantages over the traditional biodiesel production method ${ }^{57,58)}$.

\subsubsection{Enzymatic catalyzed transesterification}

Biocatalysts (enzymes) had been investigated as the means to overcome the challenges presented by chemical catalysts $^{59)}$. Lipase is the most commonly used enzyme in biodiesel production, was an effective catalyst that converts all of the FFA content in the WCO to fatty acid methyl ester. However, enzyme - catalysed transesterification(Fig. 5) was not yet used at an industrial scale for several reasons, such as the high cost of lipase, inhibition of lipase by methanol, glycerol adsorption on lipase, and long reaction time.

Enzyme-catalyzed reactions are less energy intensive, do not promote side reactions and were more environmentally friendly ${ }^{60,61)}$.

4.1.5 Microwave assisted transesterification

Microwave assisted transesterification(Fig. 6) was

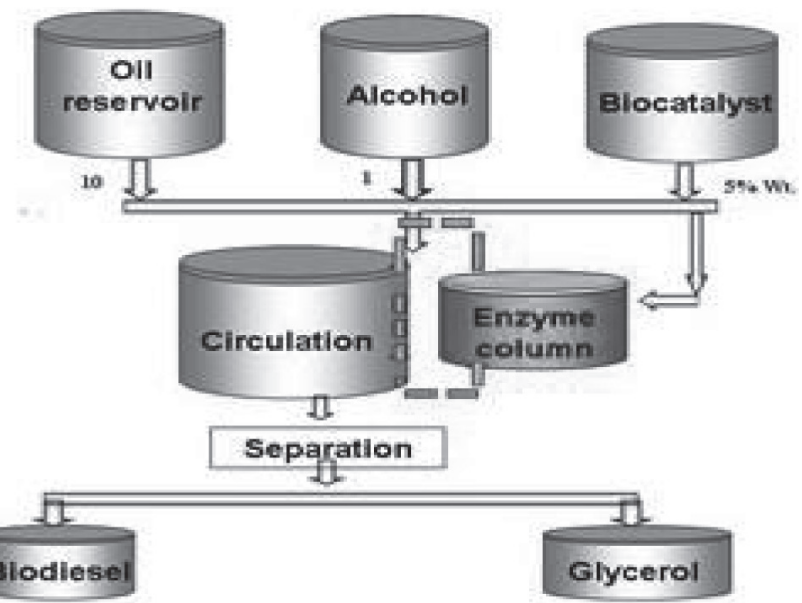

Fig. 5 Enzyme catalyzed transesterification.

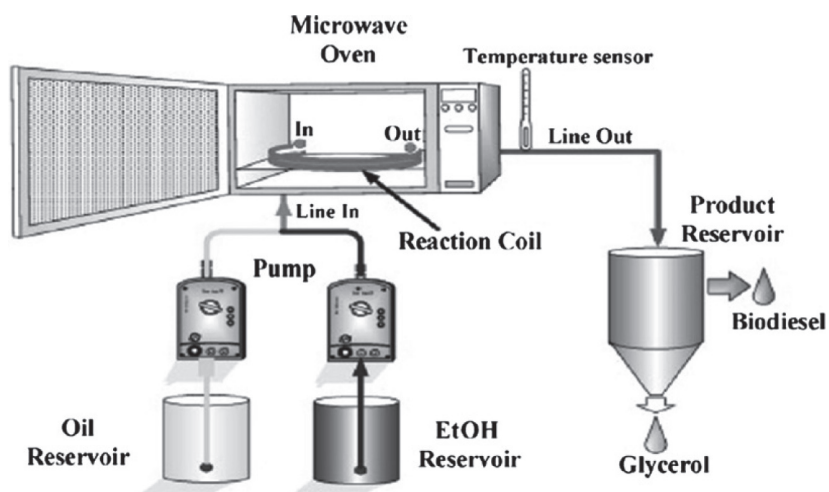

Fig. 6 Schematic diagram of a continuous microwave biodiesel production process ${ }^{1)}$. another alternative energy tool which could be used for the production of biodiesel. Due its advantages like reduced reaction time, better yield and environmentally benign compared to conventional heating, it was becoming the obvious choice of many researchers. Microwave transfer energy had a tendency to oscillate polar ends of molecules or ions continuously. As a result the collision and friction between the moving molecules generate heat. Heat was therefore directly deposited into the reaction media and results in rapid temperature increase throughout the sample. Several studies on micro wave assisted transesterification had been reported using different catalyst system and they observed that it offers fast, low oil: methanol ratio, easy operation, reduced energy consumption and minimum by products ${ }^{1,37)}$.

4.1.6 Ultrasound assisted transesterification

The demand for biodiesel in the world was sharply increasing. Thus, increasing the production rate for biodiesel in order to meet the demand seems to be essential. Therefore, new accelerating technologies were of great interest among researchers in this area.

Ultrasonication provides the mechanical energy for mixing and the required activation energy for initiating the transesterification reaction. Ultrasonication increases the chemical reaction speed and yield of the transesterification of vegetable oils / animal fats (Fig. 7 $)^{62,63)}$.

4.1.7 Two-step subcritical water and supercritical methanol transesterification

Esterification had commercial utility beyond biodiesel synthesis. Esters were used as solvents in many applications such as cosmetics and in the lubricant industry. Esterification was usually catalyzed by strong mineral acids

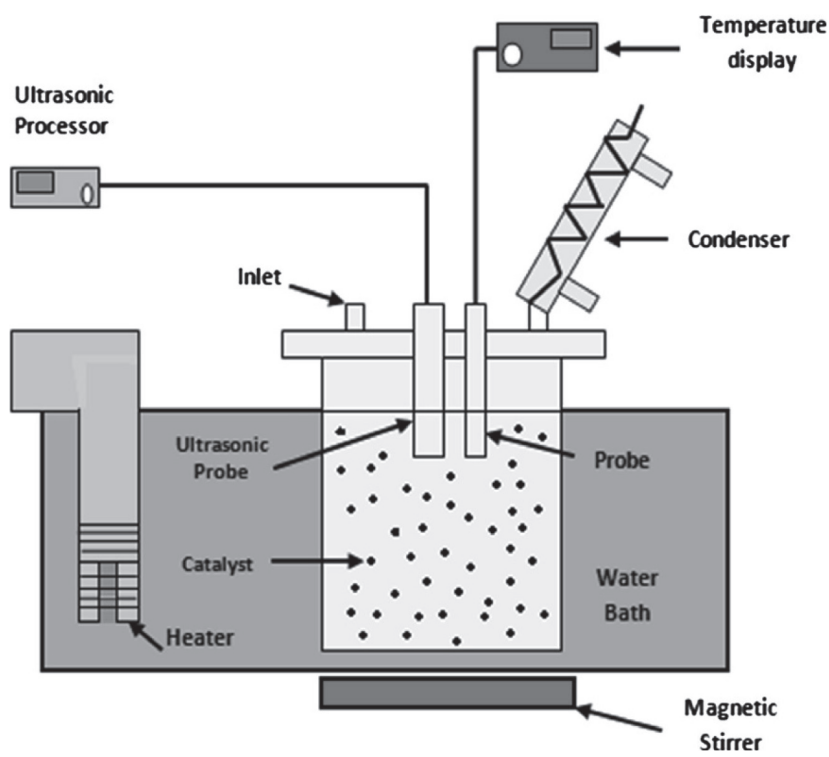

Fig. 7 Schematic diagram of an experimental set-up used for ultrasonic - assisted biodiesel production process ${ }^{1)}$. 


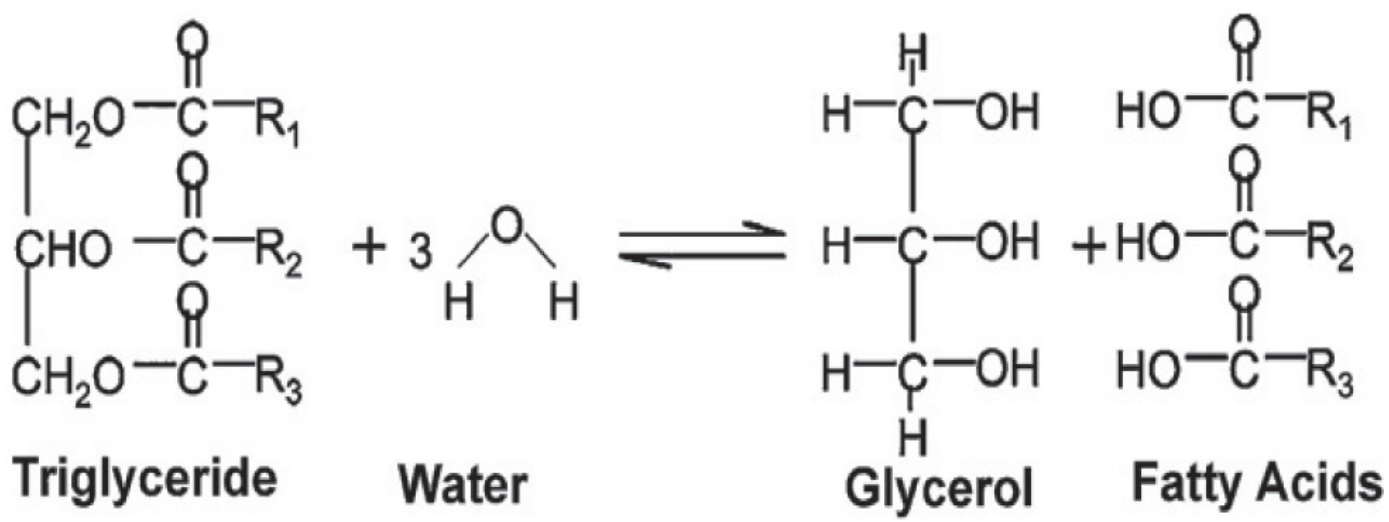

Scheme 2 shows step 1: Hydrolysis of Triglyceride.

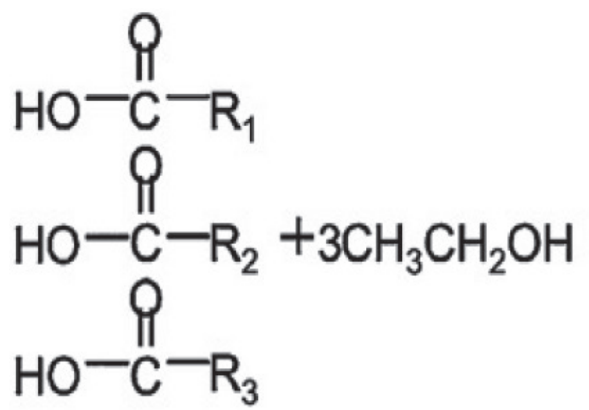

Fatty Acids

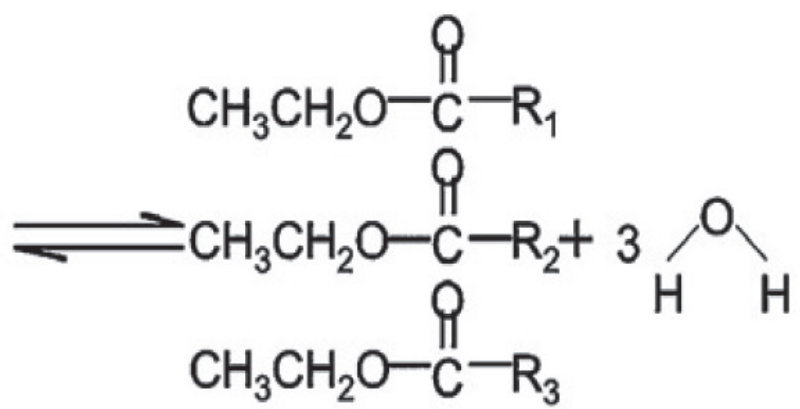

Biodiesel (Ethyl Ester) Water

Scheme 3 shows step 2: Esterification of fatty acids.

(e.g., sulfuric or hydrochloric acid), which were corrosive and environmentally hazardous. Therefore, there was a need to develop a more environmentally friendly process to produce esters. Noncatalytic esterification was an interesting possibility ${ }^{64,65)}$. Scheme 2 and Scheme 3 show Hydrolysis and esterification reactions in two-step synthesis of biodiesel ${ }^{40)}$.

Moreover, the reaction did not require a large excess of alcohol, and it could tolerate the presence of modest amounts of water in the feed stream.

\section{Conclusion}

Currently, utilization of the non-edible oils as feedstocks for biodiesel production had become more attractive. The not suitability for food, high oil content and the low cost of cultivation were the main advantages offered using such feed stocks. Subcritical water technology seemed to be the greener alternative method for the different oil seeds extraction. The short extraction time and the elimination of using solvents were the major benefits of using such technology. The most practical processes for biodiesel production was by transestrification reaction which was a catalyzed reaction of vegetable oil in the presence of alcohol to yield biodiesel and glycerol. Also the noncatalytic esterification was an interesting possibility because the reaction did not require a large excess of alcohol.

\section{Acknowledgment}

The authors would like to acknowledge the Egyptian Science and Technological Development Fund (STDF) for supporting the present study under the umbrella of the research project entitled "Innovative Green Extraction Technology for Medicinal Plants” with Project ID 5767.

\section{References}

1) Kiakalaieh, A.; Amin, N.; Mazaheri, H. A review on novel processes of biodiesel production from waste cooking oil. Applied Energy 104, 683-710 (2014).

2) Kumaran, P.; Mazlini, N.; Hussein, I.; Nazrain, M.; Khairul, M. Technical feasibility studies for Langkawi WCO (waste cooking oil) derived-biodiesel. Energy 36, 1386-1393 (2011).

3) Mofijur, M.; Atabani, A.; Masjuki, H.; Kalam, M.; Masum, B. A study on the effects of promising edible and 
non-edible biodiesel feedstocks on engine performance and emissions production: A comparative evaluation. Renewable and Sustainable Energy Reviews 23, 391-404 (2013).

4) Yan, J.; Yan, Y.; Liu, S.; Hu, J.; Wang, G. Preparation of cross-linked lipase-coated micro-crystals for biodiesel production from waste cooking oil. Bioresource Technol. 102, 4755-4758 (2011).

5) Al-Mulla, E., Yunus, W.; Ibrahim, N.; A. Rahman, M. Difatty Acyl Urea from Corn Oil: Synthesis and Characterization. J. Oleo Sci. 59, 157-160 (2010).

6) Dehkordi, A.; Ghasemi, M. Transesterification of waste cooking oil to biodiesel using $\mathrm{Ca}$ and $\mathrm{Zr}$ mixed oxides as heterogeneous base catalysts. Fuel Process. Technol. 97, 45-51 (2012).

7) Al-Mulla, E., Yunus, W.; Ibrahim, N.; A. Rahman, M. Enzymatic Synthesis of Fatty Amides from Palm Olein. J. Oleo Sci. 59, 59-64(2010).

8) Abdelmoez, W.; Mustafa, A. Oleochemical Industry Future through Biotechnology. J. Oleo Sci. 63, 545-554 (2014).

9) Uzun, B.; Kılıç, M.; Özbay, N.; Pütün, A.; Pütün, E. Biodiesel production from waste frying oils: Optimization of reaction parameters and determination of fuel properties. Energy 44, 347-351 (2012).

10）Wu, T.; Su, S.; Wang, H.; Lin, Y.; Gung, S.; Lin, M.; Sun, I. Electrochemical studies and self diffusion coefficients in cyclic ammonium based ionic liquids with allyl substituents. Electrochimica Acta 56, 3209-3218(2011).

11) Deshmane, V.; Adewuyi, Y. Synthesis and kinetics of biodiesel formation via calcium methoxide base catalyzed transesterification reaction in the absence and presence of ultrasound. Fuel 107, 474-482 (2013).

12) Chen, K.; Lin, Y.; Hsu, K.; Wang, H. Improving biodiesel yields from waste cooking oil by using sodium methoxide and a microwave heating system. Energy 38, 151$156(2012)$.

13) Sankaranarayanan, S.; Antonyraj, C.; Kannan, S. Transesterification of edible, non-edible and used cooking oils for biodiesel production using calcined layered double hydroxides as reusable base catalysts. Bioresource Technol. 109, 57-62 (2012).

14) Patil, P.; Gude, V.; Reddy, H.; Muppaneni, T.; Deng, S. Biodiesel production from waste cooking oil using sulfuric acid and microwave irradiation processes. J. Environ. Protect. 3, 107-113(2012).

15) Torres, E.; Cerqueira, G.; Ferrer, T.; Quintella, C.; Raboni, M.; Torretta, V.; Urbini, G. Recovery of different waste vegetable oils for biodiesel production: A pilot experience in Bahia State, Brazil. Waste Management 33, 2670-2674(2013).

16) Liu, Y.; Chen, D.; Yan, Y.; Peng, C.; Xu, L. Biodiesel synthesis and conformation of lipase from Burkholderia cepacia in room temperature ionic liquids and or- ganic solvents. Bioresource Technology 102, 1041410418(2011).

17) Lin, Y.; Yang, P.; Chen, S.; Lin, J. Improving biodiesel yields from waste cooking oil using ionic liquids as catalysts with a microwave heating system. Fuel Processing Technol. 115, 57-62 (2013).

18) Chen, P.; Chen, W.; Lai, S.; Chang, C. Solubility of Jatropha and Aquilaria oils in supercritical carbon dioxide at elevated pressures. J. Supercritical Fluids 55, 893-897 (2011).

19) Sammaiah, A.; Padmaja, K.; Prasad, R. Synthesis of epoxy jatropha oil and its evaluation for lubricant properties. J. Oleo Sci. 63, 637-643(2014).

20) Atabani, A.; Mahlia, T.; Masjuki, H.; Badruddin, I.; Yussof, H.; Chong, W.; Lee, K. A comparative evaluation of physical and chemical properties of biodiesel synthesized from edible and non-edible oils and study on the effect of biodiesel blending. Energy 58, 296-304 (2013).

21) Maddikeri, G.; Pandit, A.; Gogate, P. Adsorptive removal of saturated and unsaturated fatty acids using ion-exchange resins. Ind. Eng. Chem. Res. 51, 6869$6876(2012)$.

22） Ong, H.; Silitonga, A.; Masjuki, H.; Mahlia, T.; Chong, W.; Boosroh, M. Production and comparative fuel properties of biodiesel from non-edible oils: Jatropha curcas, Sterculia foetida and Ceiba pentandra. Energy Conv. Manag. 73, 245-255(2013).

23) Casas, A.; Ramos, M.; Parez, A. Kinetics of chemical interesterification of sunflower oil with methyl acetate for biodiesel and triacetin production. Chem. Eng. J. 171, 1324-1332 (2011).

24) Yusuf, N.; Kamarudin, S.; Yaakub, Z. Overview on the current trends in biodiesel production. Energy Conv. Manag. 52, 2741-2751(2011).

25) Lam, M.; Lee, K. Catalytic transesterification of high viscosity crude microalgae lipid to biodiesel: effect of co-solvent. Fuel Process. Technol. 110, 242-248 (2013).

26) Balat, M. Potential alternatives to edible oils for biodiesel production - A review of current work. Energy Conv. Manag. 52, 1479-1492 (2011).

27) Satyarthi, J.; Srinivas, D.; Ratnasamy, P. Hydrolysis of vegetable oils and fats to fatty acids over solid acid catalysts. Appl. Catal. A: General 391, 427-435 (2011).

28) Madankar, C.; Pradhan, S.; Naik, S. Parametric study of reactive extraction of castor seed (Ricinus communis) for methyl ester production and its potential use as bio lubricant. Industrial Crops and Products 43, 283-290 (2013).

29) Kansedo, J.; Lee, K. Process optimization and kinetic study for biodiesel production from non-edible sea mango (Cerbera odollam) oil using response surface 
methodology. Chem. Eng. J. 214, 157-164(2013).

30) Dias, J.; Araújo, J.; Costa, J.; Alvim-Ferraz, M.; Almeida, M. Biodiesel production from raw castor oil. Energy 53, 58-66 (2013).

31) Qian, J.; Shi, H.; Yun, Z. Preparation of biodiesel from Jatropha curcas L. oil produced by two-phase solvent extraction. Bioresouce Technol. 101, 7025-7031 (2010).

32) Carr, A.; Mammucari, R.; Foster, N. A review of subcritical water as a solvent and its utilisation for the processing of hydrophobic organic compounds. Chem. Eng. J. 172, 1-17(2011).

33) Chen, C.; Cheng, Y.; Ching, Y.; Hsiang, D.; Chang, C. Green production of energetic Jatropha oil from deshelled Jatropha curcas L. seeds using supercritical carbon dioxide extraction. J. Supercrit. Flu. 66, 137143(2012).

34) Chesterfield, D.; Rogers, P.; Al-Zaini, E.; Adesina, A. Production of biodiesel via ethanolysis of waste cooking oil using immobilised lipase. Chem. Eng. J. 207208, 701-710 (2012).

35) Al-Widyan, M.; Al-Muhtaseb, M. Experimental investigation of jojoba as a renewable energy source. Energy Conv. Manag. 51, 1702-1707(2010).

36) Sapna Eipeson, V.; Manjunatha, J.; Srinivas, P.; Sindhu Kanya, T. Extraction and recovery of karanjin: A value addition to karanja (Pongamia pinnata) seed oil. Industrial Crops and Products 32, 118-122 (2010).

37) Fauzi, A.; Amin, N. An overview of ionic liquids as solvents in biodiesel synthesis. Renew. Sust. Energ. Rev. 16, 5770-5786 (2012).

38) Jin, Z.; Han, S.; Zhang, L.; Zheng, S.; Wang, Y.; Lin, Y. Combined utilization of lipase-displaying Pichia pastoris whole-cell biocatalysts to improve biodiesel production in co-solvent media. Bioresource Technol. 130, 102-109 (2013).

39) Mofijur, M.; Masjuki, H.; Kalam, M.; Atabani, A.; Shahabuddin, M.; Palash, S.; Hazrat, M. Effect of biodiesel from various feedstocks on combustion characteristics, engine durability and materials compatibility: A review. Renewable and Sustainable Energy Reviews 28, 441-455 (2013).

40) Karmakar, A.; Karmakar, S.; Mukherjee, S. Biodiesel production from neem towards feedstock diversification:Indian perspective. Renewable and Sustainable Energy Reviews 16, 1050-1060 (2012).

41) Atabani, A.; Silitonga, A.; Ong, H.; Mahlia, T.; Masjuki, H.; Badruddin, I.; Fayaz, H. Non-edible vegetable oils: A critical evaluation of oil extraction, fatty acid compositions, biodiesel production, characteristics, engine performance and emissions production. Renewable and Sustainable Energy Reviews 18, 211-245 (2013).

42) Mathiarasi, R.; Mugesh kanna, C.; Partha, N. Trans- esterification of soap nut oil using novel catalyst. $J$. Saudi Chem. Soc. doi:10.1016/j.jscs.2013.07.006 (2013).

43) Morais, S.; Mata, T.; Martins, T.; Pinto, G.; Costa, C. Simulation and life cycle assessment of process design alternatives for biodiesel production from waste vegetable oils. J. Cleaner Prod. 18, 1251-1259 (2010).

44) Abdelmoez, W.; Abdelfatah, R.; Tayeb, A. Extraction of Cottonseed Oil Using Subcritical Water Technology. AIChE J. 57, 2353-2359 (2011).

45) Abdelmoez, W.; Abdelhamid, M.; Yoshida, H. Extraction of Jojoba Oil Using Subcritical Water Technology. Recent Patents on Chemical Engineering 5, 63-70 (2012).

46) Abdelmoez, W.; Nage, S.; Bastawess, A.; Ihab, A.; Yoshida, H. Subcritical water technology for wheat straw hydrolysis to produce value added products. J. Cleaner Prod. 70, 68-77 (2014).

47) Amin, I.; Parnas, R. Continuous production of biodiesel from waste cooking oil in a reactive distillation column catalyzed by solid heteropolyacid: Optimization using response surface methodology(RSM). Fuel 94, 156164 (2012).

48) Karmakar, A.; Karmakar, S.; Mukherjee, S. Properties of various plants and animals feedstocks for biodiesel production. Bioresource Technol. 101, 7201-7210 (2010).

49) Charoenchaitrakool, M.; Thienmethangkoon, J. Statistical optimization for biodiesel production from waste frying oil through two-step catalyzed process. Fuel Processing Technol. 92, 112-118(2011).

50) Bankovic-Ilic, I.; Stamenkovic, O.; Veljkovic, V. Biodiesel production from non-edible plant oils. Renewable and Sustainable Energy Reviews 16, 36213647 (2012).

51) Tsai, Y.; Lin, H.; Lee, M. Biodiesel production with continuous supercritical process: Non-catalytic transesterification and esterification with or without carbon dioxide. Bioresource Technol. 145, 362-369 (2013).

52) Lim, S.; Hoong, S.; Teong, L.; Bhatia, S. Supercritical fluid reactive extraction of Jatropha curcas L. seeds with methanol: A novel biodiesel production method. Bioresource Technol. 101, 7169-7172(2010).

53) Yaakob, Z.; Mohammad, M.; Alherbawi, M.; Alam, Z.; Sopian, K. Overview of the production of biodiesel from Waste cooking oil. Renewable and Sustainable Energy Reviews 18, 184-193(2013).

54) Shang, Q.; Jiang, W.; Lu, H.; Liang, B. Properties of Tung oil biodiesel and its blends with 0\# diesel. Bioresource Technol. 101, 826-828(2010).

55) Borugadda, V.; Goud, V. Biodiesel production from renewable feedstocks: Status and opportunities. Renewable and Sustainable Energy Reviews 16, 47634784(2012). 
56) Maddikeri, G.; Pandit, A.; Gogate, P. Ultrasound assisted interesterification of waste cooking oil and methyl acetate for biodiesel and triacetin production. Fuel Processing Technol. 116, 241-249(2013).

57) Jiang, Y.; Lu, J.; Sun, K.; Ma, L.; Ding, J. Esterification of oleic acid with ethanol catalyzed by sulfonated cation exchange resin: Experimental and kinetic studies. Energy Conv. Manag. 76, 980-985(2013).

58) Pinnarat, T.; Savage, P. Noncatalytic esterification of oleic acid in ethanol. J. Supercrit. Flu. 53, 53-59 (2010).

59) Abdelmoez, W.; Mostafa, N. A.; Mustafa, A. Utilization of oleochemical industry residues as substrates for lipase production for enzymatic sunflower oil splitting. J. Clean Prod. 59, 290-297 (2013).

60) Ilham, Z.; Shiro, S. Two-step supercritical dimethylcarbonate method for biodiesel production from Jatropha curcas oil. Bioresource Technol. 101, 2735-2740 (2010).

61) Lim, S.; Teong L. Recent trends,opportunities and challenges of biodiesel in Malaysia: an overview. Renewable and Sustainable Energy Reviews 14, 938$954(2010)$.

62) Torres, J.; Jerman, M.; Gregorc, A.; Lisec, I.; Dorado, M.; Kegl, P. Physical and chemical properties of ethanol-diesel fuel blends. Fuel 90, 795-802 (2011).

63) Hoekman, S.; Broch, A.; Robbins, C.; Ceniceros, E.; Natarajan, M. Review of biodiesel composition, properties, and specifications. Renewable and Sustainable Energy Reviews 16, 143-169 (2012).

64) Dantas, M.; Albuquerque, A.; Soledade, L.; Queiroz, N.; Maia, A.; Santos, M. Biodiesel from soybean oil, castor oil and their blends Oxidative stability by PDSC and rancimat. J. Therm. Anal. Calor. 106607-106611 (2011).

65) Teixeira, L.; Couto, M.; Souza, G.; Filho, J.; Assis, Guimaraes, P. Characterization of beef tallow biodiesel and their mixtures with soybean biodiesel and mineral diesel fuel. Biomass and Bioenergy 34, 438-441 (2010). 